established role of this brain region in conditioning of autonomic processes during emotional learning situations ${ }^{8,9}$.

Considered together with our previous study ${ }^{2}$, these findings support the view that the influence of emotional arousal on conscious, long-term memory in humans involves $\beta$-adrenergic receptor activation and influences mediated by the amygdaloid complex. Furthermore these processes seem not to be required for normal retention in non-emotionally arousing circumstances.

\section{Larry Cahill}

Center for the Neurobiology of Learning

and Memory,

University of California, Irvine,

California 92717-3800, USA

Ralf Babinsky

Hans J. Markowitsch

Physiological Psychology,

University of Bielefeld,

PO Box 100131

D-33501 Bielefeld, Germany

James L. McGaugh

Center for the Neurobiology of Learning

and Memory and Department of

Psychobiology,

University of California, Irvine,

California 92717-3800, USA

\section{A methanotrophic carnivorous sponge}

SIR - Associations between methanotrophic bacteria and several species of mytilids and a pogonophore have been described in deep-sea communities surrounding hydrothermal vents and cold seeps ${ }^{1}$. We report here a new symbiosis between a sponge and methanotrophic bacteria. The $\delta^{13} \mathrm{C}$ values and distribution indicate that the sponge is nutritionally reliant on its methanotrophic symbionts. Ultrastructural evidence indicates intracellular digestion of the bacteria. Intracellular symbionts were found in brooded embryos, indicating direct transmission of the symbionts between generations.

The sponge, Cladorhiza sp., belongs to a unique deep-sea family, Cladorhizidae (Demospongiae), which are carnivorous, and lack an aquiferous system ${ }^{2}$. The specimens were collected from a mud volcano in the Barbados Trench at a depth of 4,943 $\mathrm{m}$. Large aggregations of hundreds of individuals (up to $1.5 \mathrm{~m}$ in diameter and $40 \mathrm{~cm}$ high) were found around the periphery of the volcano's eye, where the highest concentrations of methane were document-

1. Nelson, D. C. \& Fisher, C. R. in Microbiology of Deep-Sea Hydrothermal Vent Habitats (ed. Karl, D. M.) 125-168 (CRC Press, Boca Raton, FL, 1995).

2. Vacelet, J. \& Boury-Esnault, N. Nature 373, 333-335 (1995).

3. Le Pichon, X. et al. J. geophys. Res. 95, 8931-8943 (1990).

4. Fisher, C. R. et al. Mar. Ecol. Prog. Ser. 103, 45-55 (1994).

5. Reiswig, H. M. P.S.Z.N.I. mar. Ecol. 2, 273-293 (1981).

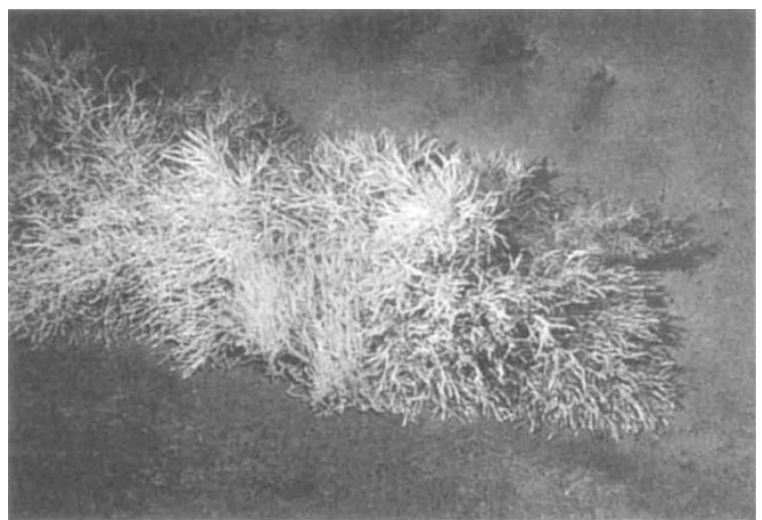

FIG. 1 Large bush of cladorhizid sponge observed with the submersible Nautile at 4,943 $\mathrm{m}$ in the mud volcano Atalante, in the Barbados Trench, during the MANON cruise. The bushes were most abundant and larger around the volcano eye where large amounts of methane were detected.

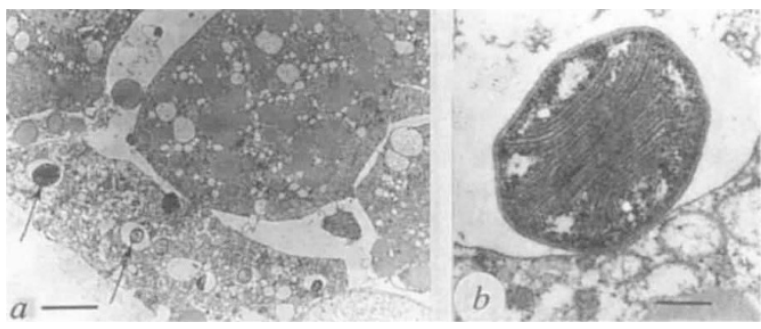

FIG. 2 Transmission electron micrographs of microsymbionts within the surface cells of the embryo. a, Two bacterial types (arrows). Scale bar, $2.7 \mu \mathrm{m}$. $b$, Magnification of a methanotrophic symbiont with stacked lamellae. Unlike bacteria inside somatic cells, there is no evidence of symbiont degradation in the embryo cells. Scale bar, $0.3 \mu \mathrm{m}$.

ed $^{3}$ (Fig. 1). Before this discovery, cladorhizids were known to occur only in low densities as discrete individuals.

Two ultrastructural types of symbiotic bacteria were observed in the sponge tissue (Fig. 2). (1) Coccoid cells with stacked intracytoplasmic membranes and electronlucent droplets. This morphology is typical of some methanotrophic bacteria, including methanotrophic symbionts described in other invertebrates. (2) Smaller, oval-torod-shaped cells. Both symbionts occurred intercellularly, apparently healthy, with frequent division stages, and intracellularly in phagocytic cells in various stages of degradation, suggesting a nutritional relationship between host and symbionts.

Many symbionts were also observed within flattened cells at the surface of embryos. In this location, no degenerating symbionts were apparent. This suggests a mechanism for direct transmission of the symbionts between generations and is reminiscent of littoral 'bacteriosponges', where bacteria are transmitted between generations in oocytes.

Sponge tissues were tested for the presence of key enzymes of methylotrophic and chemoautotrophic sulphuroxidizing bacteria. Significant methanol dehydrogenase activity was found, indicating the presence of abundant methanotrophic symbionts. Low activities of ribulose 1,5-bisphosphate (RuBP) carboxylase were detected, which could be due to type $\mathrm{x}$ methanotrophs, low activity in chemoautotrophic symbionts, or surface bacteria. Neither ATP sulphurylase nor adenosine $-5^{\prime}$-phosphosulphonate reductase activities were detectable.

The very negative tissue $\delta^{13} \mathrm{C}$ values (from -48.4 to $-48.8 \%$ in three samples) are also consistent with the presence of methanotrophic symbionts. The relatively light tissue $\delta^{15} \mathrm{~N}$ values $(+2.0$ to $2.9 \%$ ) are within the range reported for other vent and seep fauna, and reflect significant input of organic nitrogen of local origin $^{4}$.

These observations indicate that the symbionts are methanotrophic and suggest that the sponge derives some of its nutrition from the intracellular digestion of the symbionts. A similar mechanism has been suggested for a variety of other chemoautotrophic and methanotrophic symbioses 1 , as well as for littoral 'bacteriosponges' with heterotrophic symbionts 5 .

The sponge morphology, erect with branching processes bearing a cover of hook-like spicules, suggests they may also feed on swimming prey, as do other cladorhizids $^{2}$. This was supported by the presence of debris from small crustaceans on the sponges. The relative importance of carnivory and methanotrophy in sponge nutrition cannot be evaluated, but it is unlikely that such aggregations of carnivorous sponges could survive in the deep sea without a nutritional symbiosis.

Carnivory has allowed cladorhizid sponges to colonize the deepest oceans, although they are normally small and rare. The association with methanotrophic bacteria, with their unusual feeding strategy, allows a large biomass, and illustrates the extreme adaptability of Porifera.

Jean Vacelet, Nicole Boury-Esnault

Centre d'Océanologie de Marseille,

Université de la Méditerranée - URA

CNRS no. 41 ,

Station Marine d'Endoume,

13007 Marseille, France

Aline Fiala-Medioni

Observatoire Océanologique,

Laboratoire Arago,

66650 Banyuls-sur-Mer, France

C. R. Fisher

Department of Biology,

Pennsylvania State University,

University Park, Pennsylvania 16802, USA 